\title{
ПРОБЛЕМИ ІНСТИТУЦІОНАЛЬНОГО ЗАБЕЗПЕЧЕННЯ ФОРМУВАННЯ ЕКОЛОГІЧНО СТІЙКИХ АГРОЛАНДШАФТІВ В УКРАЇНІ
}

\author{
аспірант Наталія Вікторівна Комарова \\ Україна, м. Київ, Інститут агроекологї і природокористування \\ Національної академії аграрних наук
}

DOI: https://doi.org/10.31435/rsglobal_ijite/30062019/6534

\section{ARTICLE INFO}

Received 20 April 2019

Accepted 21 June 2019

Published 30 June 2019

\section{KEYWORDS}

agro resource potential, agro landscape, institutional providing, agro ecological safety, commodity production of plant growing, balanced land use.

\begin{abstract}
Increase in the level of anthropogenic loading on agro ecosystem, which is the result of an increase in the amount of production of marketable crop production in violation of the requirements for reproduction and preservation of agro resource potential, leads to negative destructive changes in agro landscapes, what threatens agro ecological and food security. Under the existing organization of commodity production of crop production there are no trends in the implementation of land-use measures, and the priority is to increase profits, increase in yield, extension of arable land within the narrowing of agricultural land provoke the spread of erosion and degradation processes, reduction of humus stock and land fertility level. Implementation of measures for the restoration and preservation of agro resource potential demanding radical changes from scientifically positions. The systematization of agro ecological safety factors will promote the search for optimal organizational and economic decisions, implementation of agricultural land use. The subject of the research is a set of theoretical aspects of improvement organizational and economic conditions of balanced land use and institutional support, which will ensure the formation of environmentally sustainable agricultural landscapes.
\end{abstract}

Citation: N. V. Komarova. (2019) Problemy Instytutsionalnoho Zabezpechennia Formuvannia Ekolohichno Stiikykh Ahrolandshaftiv $\mathrm{v}$ Ukraini. International Journal of Innovative Technologies in Economy. 4(24). doi: 10.31435/rsglobal_ijite/30062019/6534

Copyright: (C) 2019 N. V. Komarova. This is an open-access article distributed under the terms of the Creative Commons Attribution License (CC BY). The use, distribution or reproduction in other forums is permitted, provided the original author(s) or licensor are credited and that the original publication in this journal is cited, in accordance with accepted academic practice. No use, distribution or reproduction is permitted which does not comply with these terms.

Постановка проблеми. Аналіз характеристик процесу землекористування, який запроваджено в Україні, і сільськогосподарського спрямування зокрема, доводить його незбалансований рівень, що підтверджується обсягами процесів деградації грунтового покриву. Забезпечення прийнятного рівня агроекологічної безпеки при збереженні тенденції збільшення прибутків агропідприємств рослинницького профілю вимагає ощадливого ставлення до використання основного ресурсного потенціалу - земель сільськогосподарського призначення. За існуючих соціально-економічних умов та 3 врахуванням євроінтеграційних прагнень України розв'язання цих завдань вимагає запровадження організаційно-економічних реформ інституційної складової з орієнтацією на посилення відповідальності господарюючих суб'єктів за якісні характеристики ресурсно-виробничої бази, тобто за стан агроресурсного потенціалу регіону. Можна стверджувати, що формування фінансово-економічної залежності прибутків агропідприємців має формуватись не лише від обсягів збору врожаїв та від якісного стану продукції, а і від стану грунтового покриву, якого набувають землі сільськогосподарського призначення в результаті агровиробничого використання.

Аналіз останніх досліджень i публікацій. Пошук шляхів розв'язання проблем інституціонального забезпечення збалансованого сільськогосподарського землекористування 
привертає увагу широкого кола дослідників. Зокрема, питанням оптимізації використання агроугідь 3 врахуванням впливу ерозійних процесів присвячено праці Камінського В.Ф., Сайка В.Ф., Третяк В.М., Третяка А.М., Шикули М.К., Новаковського Л.Я., Ковди В.А. Економічні аспекти організації землекористування досліджувались Лукіновим I.I., Логвіновим Л.Д., Добряком Д.С., Корчинською О.А., Бамбіндрою Д.І., Носком Б.С., Тараріко О.Г., Данилишиним Б.М. та ін.

На нашу думку, сформовані дотепер організаційно-економічні умови господарювання на основі використання земель сільськогосподарського призначення при товарному виробництві рослинництва не забезпечують достатньою мірою відтворення і збереження родючості земель, орієнтовані на нарощування економічної ефективності агровиробничих процесів за рахунок виснаження агроресурсного потенціалу. За умов такого підходу активізуються процеси деградації та ерозії земель, що потребує докорінних змін у організації запровадження системи землеохоронних заходів у напрямку підвищення організаційноекономічної відповідальності землекористувачів за якість земель. Відтворення і збереження агроресурсного потенціалу вимагає запровадження науково обгрунтованої системи землекохоронних заходів, що обумовлює вибір мети роботи - визначення організаційноекономічних аспектів вдосконалення впровадження землеохоронної діяльності.

Постановка мети та завдань. Метою даної статті є визначення проблем та шляхів поліпшення удосконалення системи існуючих інституційних важелів забезпечення достатнього рівня агроекологічної безпеки, що мають на меті формування еколого стійких агроландшафтів.

Виклад основного матеріалу. Сучасний агроландшафт - складна природно-антропогенна система (сформована 3 ріллі, сіножатей, пасовищ, багаторічних насаджень і розташованих між ними незначних за площею ареалів лісів, чагарників, лісосмуг, боліт), яка $є$ об'єктом сільськогосподарської діяльності і середовищем життєдіяльності людини $[1,2]$. Природні екосистеми втратили під впливом антропогенного навантаження стан своєї стійкої рівноваги та набули інших ознак в результаті панування певних видів популяцій флори і фауни [3], з хиткою рівновагою через непостійну структуру біомаси, зі збідненим видовим складом. В природних ландшафтах збалансований стан досягається шляхом саморегуляції системи при відносно стабільній продуктивності, що унеможливлюється у агроекосистемах, внаслідок постійного відбору продукції людиною без належного обсягу, у більшості випадків, і компонентного складу повернення речовин у екосистему. Тому, без посилення регулятивної нормативно-законодавчої функції, спрямованої на забезпечення формування еколого-стійких агроландшафтів через інституціональне забезпечення шляхом застосування організаційно-економічних та екологоекономічних інструментів, забезпечення прийнятного рівня агроекологічної безпеки і формування еколого-стійких агроландшафтів практично не є неможливим.

Зазначене вимагає удосконалення теоретичного підгрунтя, 3 ключовим компонентом систематизації факторів та показників. Вплив факторів на рівень агроекологічної безпеки визначається показниками, з яких формується кожна з вказаних груп (рис.1).

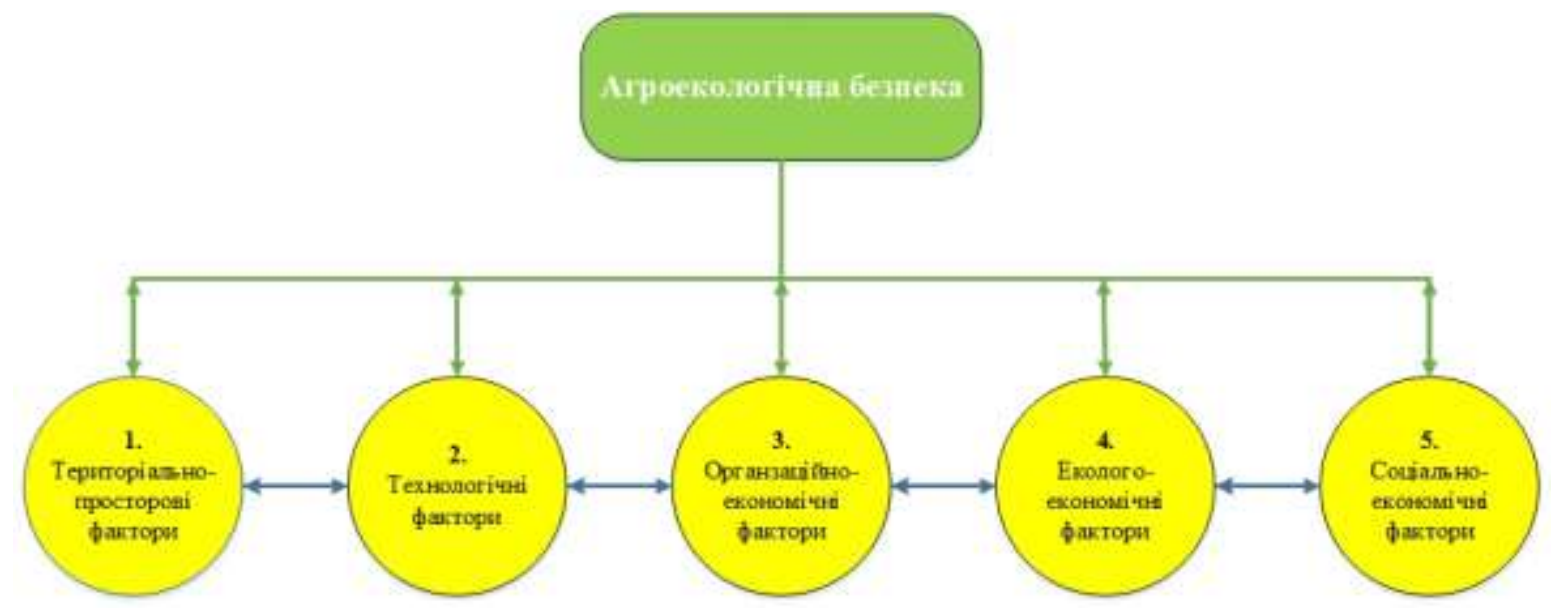

Рис. 1. Система факторів агроекологічної безпеки

Джерело: авторська розробка

Група територіально-просторових факторів характеризується показниками економічної результативності використання одиниці площі агроугідь. Вплив групи екологоекономічних факторів визначається показниками екологічної ефективності процесу 
агровиробничої діяльності, мірою зміненості природних екосистем у процесі формування агроландшафтів, що у підсумку реалізується через міру їх стійкості та рівні антропогенного навантаження на природне середовище. Значимість технологічних факторів вимірюється через технологічні параметри та через характеристики застосування різних агровиробничих технологій. Характеристики організаційно-економічної групи вимірюється економічною ефективністю агровиробничої діяльності. В свою чергу соціально-економічні фактори визначаються економічними параметрами агровиробничої діяльності на одного зайнятого та рівнем комфортності життєдіяльності у сільській місцевості, що визначається станом формування соціальної інфраструктури.

Поділ та систематизація вказаних показників носить дещо умовний характер через системність взаємозалежностей між ними, але вплив відбувається комплексно, створюючи сублімований ефект. Міра впливу кожної з груп факторів визначається організаційноекономічними, еколого-економічними, соціально-економічними умовами господарювання, тобто формується структура факторів впливу на рівень агроекологічної безпеки та стан агроландшафтів.

Сублімований ефект впливу системи факторів має як прямий, так і зворотній ефект, що відображено на рисунку 1. Наприклад, грунтово-кліматичні умови визначають технологічні відмінності агровиробничих процесів, що в свою чергу впливає не лише на формування парку агротехнологічного обладнання, a i визначає співвідношення у балансі економічних характеристики «затрати-вигоди». Існуючі обсяги виробництва товарної продукції рослинництва високою мірою визначаються технологічним розвитком, але нехтування вимогами еколого-економічного використання земель сільськогосподарського призначення в решті-решт призводить до виснаження агроресурсного потенціалу, що призводить до активізації деградації земель та процесів ерозії.

В результаті з'являється необхідність використання додаткових площ під посіви, що у комплексі зі скороченням і без того недостатнього рівня впровадження землеохоронних заходів знижує значення коефіцієнтів екологічної стабільності. 3 огляду на викладене, можемо стверджувати, що інтегральною характеристикою рівня агроекологічної безпеки і екологоекономічної ефективності сільськогосподарської діяльності можна вважати міру стійкості агроландшафтів та рівень збалансованого їх розвитку. 3 огляду на розвинену В.В. Докучаєвим методологічну концепцію вивчення грунту як «дзеркала ландшафту», засновану на комплексній оцінці системи сучасних екологічних факторів впливу з врахуванням історичного циклу формування грунтового покриву, з'являється можливість управління антропогенними екосистемами. Підхід, заснований В.В. Докучаєвим у подальшому отримав розвиток школою В.А. Ковди, за яким грунтовий покрив є компонентом ландшафту і розглядається у діалектичній єдності за трьома аспектами: як специфічна оболонка землі (педосфера), як компонент біосфери і як підсистема в природних і антропогенних екосистемах, що надає можливість управління ландшафтом і розвитком агроландшафту у тому числі.

Управління розвитком агроландшафту [4] запропоновано розглядати у двох площинах: управління земельними ресурсами - як економічну функцію держави (управління землекористуванням та відповідальність за ведення ефективного землекористування), i як організацію використання земельних ділянок (покладено на фізичних та юридичних осіб). Однак відмітимо умовність такого розподіленого підходу, адже законотворча функція, $є$ зоною відповідальності держави (державних інституцій), через яку формується вплив на земельні ресурси через управління процесом землекористування. Таким чином, посилення інституціональної компоненти здатне забезпечити збалансоване використання земельних ресурсів та формування еколого-стійких агроландшафтів. Запровадження нормативно-законодавчих вимог та обмежень щодо характеристик процесу використання земель та якісних параметрів їх агрохімічного стану повинно усунути дисбаланс у співвідношенні екологічних і економічних інтересів у процесі використання агроугідь 3 метою товарного виробництва рослинництва, який спостерігається останнім часом.

У процесі виконання дослідження нами було здійснено спробу оцінки впливу економічної ефективності господарювання при виробництві товарної продукції рослинництва (табл. 1) на показники екологічної ефективності господарювання, що у підсумковому вигляді можна виразити через динаміку гумусу у грунтовому покриві на землях сільськогосподарського призначення. 
Таблиця 1. Показники ефективності землекористування при товарному виробництві рослинництва в Україні

\begin{tabular}{|c|c|c|c|c|c|c|c|}
\hline Показник & 2010 & 2013 & 2014 & 2015 & 2016 & 2017 & $\begin{array}{c}\text { г 3 } \\
\text { втамікою } \\
\text { гумусу }\end{array}$ \\
\hline $\begin{array}{c}\text { Продуктивність праці (на 1 } \\
\text { зайнятого в } \\
\text { агровиробництві, у постій- } \\
\text { них цінах 2010 року; тис. } \\
\text { гривень) }\end{array}$ & 132,7 & 201,2 & 227,7 & 223,3 & 275,3 & 271,5 & $-0,56$ \\
\hline $\begin{array}{c}\text { Індекси валової продукції } \\
\text { сільського господарства } \\
\text { (відсотків до попереднього } \\
\text { року) }\end{array}$ & 98,5 & 95,5 & 113,3 & 102,2 & 95,2 & 106,3 & 0,1 \\
\hline $\begin{array}{c}\text { Продукція рослинництва в } \\
\text { господарствах усіх } \\
\text { категорій у розрахунку на } \\
\text { 100 га сільськогосподар- } \\
\text { ських угідь (тисяч гривень) }\end{array}$ & 334,7 & 483,6 & 500,6 & 474,2 & 520,1 & $\mathrm{H} /$ д & $-0,89$ \\
\hline $\begin{array}{c}\text { Виробництво валової } \\
\text { продукції сільського } \\
\text { господарства на одну особу } \\
\text { (у постійних цінах 2010 } \\
\text { року; гривень) }\end{array}$ & 4249 & 5559 & 5847 & 5589 & 5967 & 5865 & $-0,76$ \\
\hline Динаміка втрат гумусу, т/га & -0.37 & -0.13 & -0.20 & -0.13 & $-0,16$ & $-0,251$ & \\
\hline
\end{tabular}

Джерело даних: [5,6,7].

3 огляду на наведену статистичну інформацію прослідковується чітка тенденція до підвищення економічних показників землекористування при товарному виробництві рослинництва. продуктивність праці зросла удвічі, збільшились показники виробництва валової продукції (у цінах 2010 року) за всіма категоріями господарств у розрахунку на 100 га сільськогосподарських угідь на $55,4 \%$, одночасно з обсягами виробництва на одну особу від 4249 грн за 2010 рік до 5865 грн за 2017 рік. Зрозумілим є збільшення частки сільськогосподарського виробництва у динаміці показника валової доданої вартості від 8,4% у 2010 р. до $12,1 \%$ у 2017 р [11].

Найбільший вплив на досягнення таких результатів створено за рахунок збільшення обсягів внесення мінеральних добрив у вимірі поживних речовин у 2017 році в 1,7 разів. Також спостерігається збільшення площ, які зазнали оброблення засобами захисту рослин, у тому числі і пестицидами. Так у 2010 р. такі впливи хімізації в Україні були проведені на площі понад 12,2 млн га (у тому числі пестицидами - 10,8 млн га), а у 2016 р. ці показники становили 14,3 млн га (у тому числі пестицидами - 13,8 млн га, що склало майже $22 \%$ ).У той же час обсяги внесення органічних добрив зберігаються на постійно мінімальному рівні 0,5 т внесення під сільськогосподарські культури у розрахунку на 1 га [8].

При цьому набирають стабільності негативні тенденції у динаміці площ угідь сільськогосподарського призначення та їх структури. Попри деяке скорочення на рівні України за період оцінювання на 0,2 \%, що становить майже 87 тис. га відбувається збільшення площі ріллі на 65,9 тис. га [9].Така динаміка свідчить про збільшення рівня антропогенного навантаження на агроландшафти. Крім того, динаміка посівних площ ріллі демонструє значно вищі темпи збільшення на 2,3 \% (633 тис. га) протягом 2010 - 2017 років. Ресурсною базою окреслених тенденцій стало скорочення площ перелогів, багаторічних насаджень, тобто тих видів використання земель, які створюють екологостабілізуючий вплив на агроекосистему, сприяють підвищенню буферної здатності агроладшафтів. 


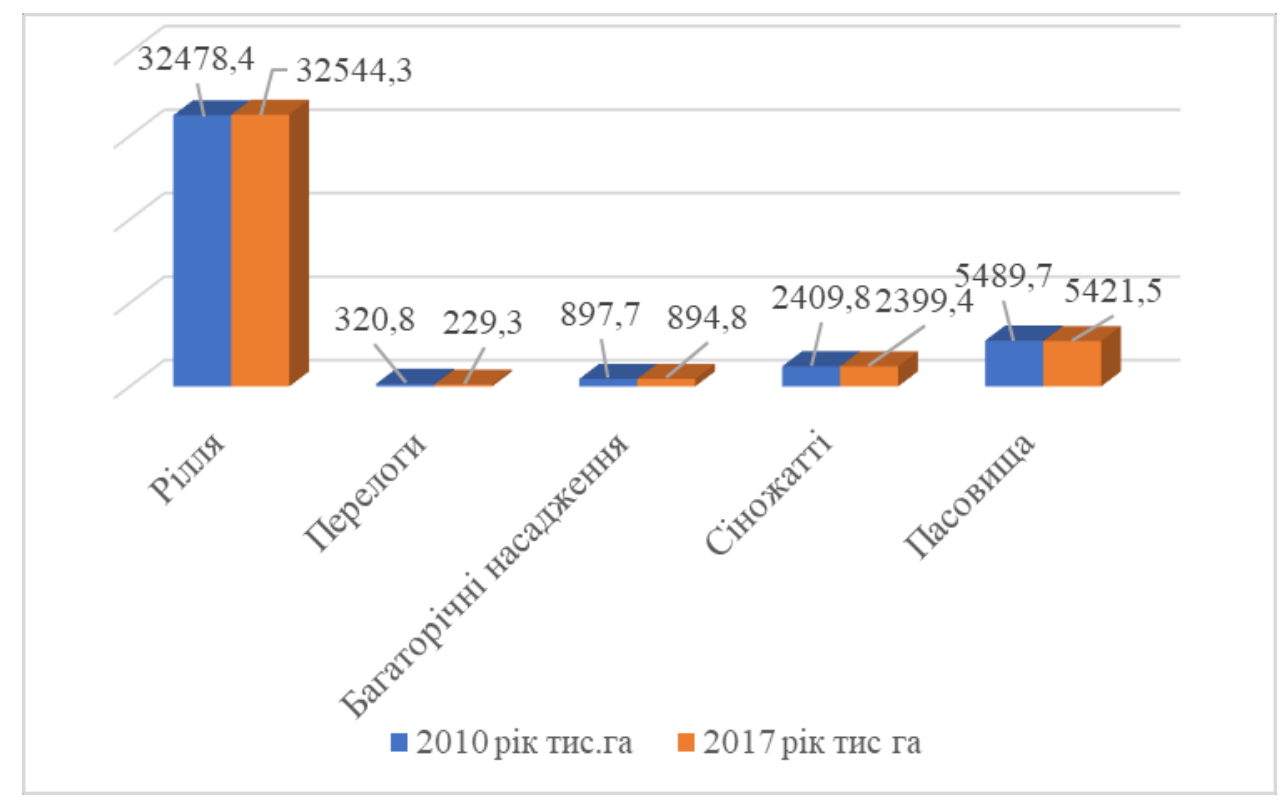

\section{Рис.2. Структура земель сільськогосподарського призначення станом на 2010 та 2017 роки}

Важливою характеристикою землекористування у рослинництві являється структура посівних площ, яка свідчить про переважання економічних інтересів над екологічними. Зокрема, площа посівів пшениці зросла від 5,3 млн га у 2000 р. до 6,1 млн га у 2010 р., а у 2017 р. цей показник становив 6,2 млн га. Площі посівів соняшника розширились більш як вдвічі і становили у 2017 р. понад 6 млн га; у 2010 р. - 4,6 млн га (для порівняння - площа екологостабілізуючих угідь у сільському господарстві станом на 01.01.2016 р. становила 8,8 млн га) [5]. Значно більші темпи приросту демонструють площі посівів ріпаку та кукурудзи на зерно, які збільшились у понад три рази від 0,2 млн га у 2000 р. - майже до 0,8 млн га у 2017 р. та від 1,4 млн га до 4,5 млн га, відповідно. Натомість площа посівів кормових культур зазнала за період 2000 - 2017 років драматичних скорочень: площі під посіви кукурудзи на зелений корм скоротились у понад 6 разів, трав'яних культур - втричі, що обумовлено скороченням поголів'я у тваринництві. В свою чергу, скорочення поголів'я у тваринництві зумовлює зменшення обсягів внесення органічних добрив під посіви, які тривалий час зберігаються на постійно низькому рівні - 1,2 - 1,3 млн т за період 2010 - 2017 pр., натомість обсяги внесення мінеральних добрив за цей же період зросли 3 0,6 до 1,1 тис. ц. При цьому у структурі добривних матеріалів спостерігається дисбаланс на користь внесення пташиного посліду, частка якого у структурі органічних добрив зросла на $10 \%$ і становить $96 \%$ проти $85 \%$ у 1991 р.

Використання пташиного посліду потребує достатньо високих затрат, а при внесенні чіткого дотримання нормативів, адже у разі високих концентрації ці добрива здатні спричинювати негативний вплив на схожість і розвиток культур. Крім того, процес виготовлення добривних матеріалів на основі пташиного посліду $\epsilon$ достатньо вартісним, потребує спеціального устаткування, а при його зберіганні відбуваються значні втрати азоту, матеріал втрачає в якості та створює негативний вплив на довкілля [10]. Дисбаланс у структурі внесених добривних матеріалів не сприяє забезпеченню збалансованого підходу у використанні земель сільськогосподарського призначення, а провокує негативні агрохімічні процеси - підкислення, ущільнення грунтів, що $є$ факторами їх ерозії, деградації та призводить до втрати гумусу агроугіддями. При цьому слід враховувати зростання рівня антропогенного навантаження у агроекосистемах, який створюється збільшенням показників врожайності майже всіх сільськогосподарських культур. Зокрема врожайність пшениці зросла від 26,8 ц/га у 2010 р. до 41,1 ц/га у 2017 р.; кукурудзи на зерно - 45,1 ц/га у 2010 р. до 55,1 ц/га у 2017 р.; соняшнику і ріпаку - від 15 та 17 ц/га до 20,2 та 27,9 ц/га у 2017 p., відповідно. Збільшення валових обсягів збору продукції з одиниці площі свідчить про посилення тиску на агроландшафти і на земельні ресурси сільськогосподарського призначення зокрема, а також про організацію землекористування, яка не сприяє формуванню еколого-стійких агроландшафтів. Крім того, спостерігається зниження рівня матеріально-ресурсного забезпечення сільськогосподарських підприємств, зокрема наявність енергетичних потужностей на кінець року у перерахунку на 100 га посівної площі скоротилась у 2017 р. відносно 2010 р. на 14,5 \%. Також спостерігається скорочення загальної кількості наявних тракторів за вказаний період на 14,5 \%, що 
свідчить про скорочення витрат на оновлення парку сільськогосподарської техніки, а отже про посилення негативного впливу технологічної групи факторів [11].

Сублімованим результатом впливу чинників, викладених вище, являється динаміка вмісту гумусу у грунтовому покриві на землях сільськогосподарського призначення. Аналізуючи дані таблиці 1 , прослідковується чітка залежність між динамікою запасів гумусу і економічною ефективністю агровиробництва. Ситуація обтяжується постійним скороченням обсягів витрат на впровадження системи землеохоронних заходів (рис. 2).

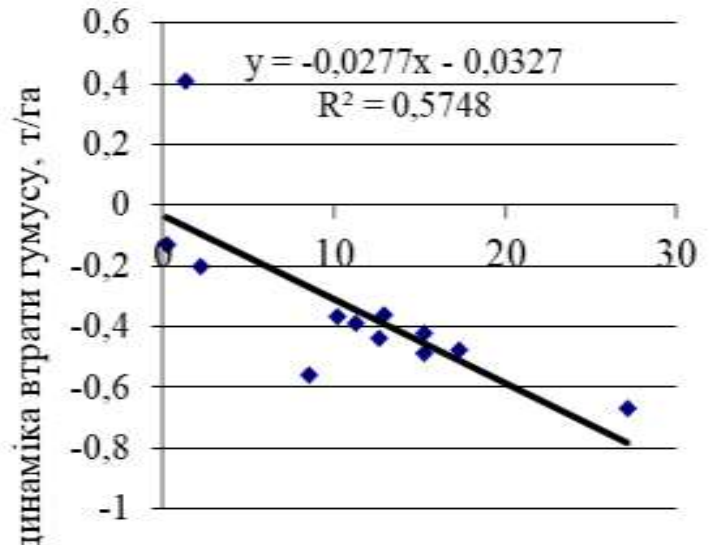

а) будівництво протиерозійних гідротехнічних споруд, км

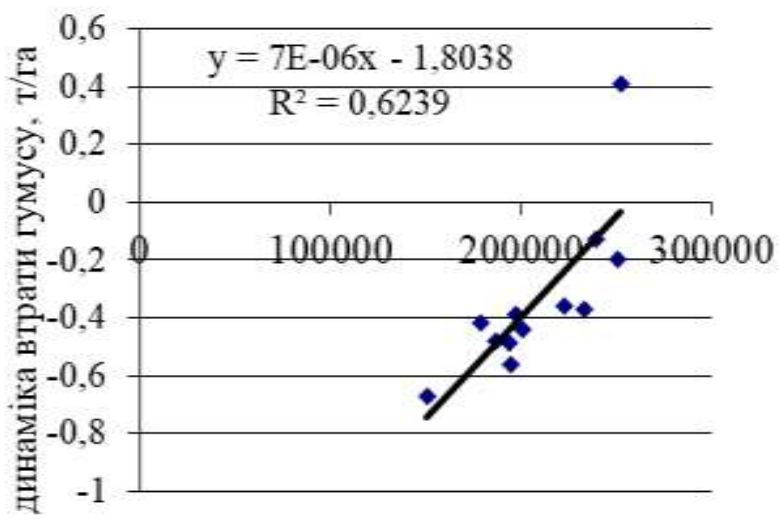

б) валова продукція агровиробнищтва у постійних цінах 2010 р, млн грн.

Рис. 3. Залежність динаміки запасу гумусу від:

а) будівництва протиерозійних гідротехнічних споруд, км;

б) обсягів виробницчтва сільськогосподарської продукції у постійних иінах 2010 р., млн грн.

Джерело: авторська розробка

За результатами десятого туру агрохімічних обстежень, який відбувся протягом $2011-$ 2015 років, офіційні значення вмісту гумусу показані дещо вищими для всіх природних зон і для України в цілому. Зокрема середньозважений показник становив 3,16 \% [12] проти результатів дев'ятого туру обстежень (2006 - 2009 років), коли це значення було 3,14\% [13]. Порівняння цих результатів викликає труднощі, через скорочення загальної обстеженої площі сільськогосподарських земель на 23 \% у останньому турі відносно попереднього (18824.7 тис. га проти 24463 тис. га). Крім того, наведена інформація щодо динаміки вмісту гумусу викликає сумніви 3 огляду на дані щодо площ еродованих земель. Так, за даними дев'ятого туру обстеження майже 40 \% площ ріллі уражені ерозією. Наведена економічна ефективність товарного виробництва рослинництва $€$ результатом існуючого організаційно-економічного підходу до землекористування, пояснює погіршення стану екологічної безпеки, що втілюється у скороченні значень коефіцієнтів екологічної стабільності території. За даними Національної доповіді про стан навколишнього природного середовища України коефіцієнт екологічної стабільності території України у 2012 році становив 0,41, а станом на 01.01.2016 року він становив 0,40, це означає, що територія відноситься до стабільно нестійкої.

Отже, існуюча ситуація у сільськогосподарському землекористуванні потребує докорінних організаційно-економічних змін у діяльності із запровадженням системи науково обгрунтованих землеохоронних заходів. Реалізація зазначених задач можлива шляхом нормативно-законодавчих та інституційних змін у напрямку розвитку системи інвентаризації і моніторингу із запровадженням функціонування системи сертифікації земель 3 послідуючою видачою дозволів на реалізацію товарного виробництва певних видів сільськогосподарських культур у комплексі із системою штрафних санкцій та рекомендацій щодо комплексу землеохоронних заходів, які підлягають обов'язковому впровадженню. Це, в свою чергу, потребує розвитку системи нормативів і показників на рівні регіонів, розбудову якої в Україні започатковано 3 прийняттям ДСТУ «Якість грунту. Показники родючості грунтів» [14]. Принципову схему організаційно-економічного удосконалення системи запровадження землеохоронної діяльності викладено на рисунку 3. 


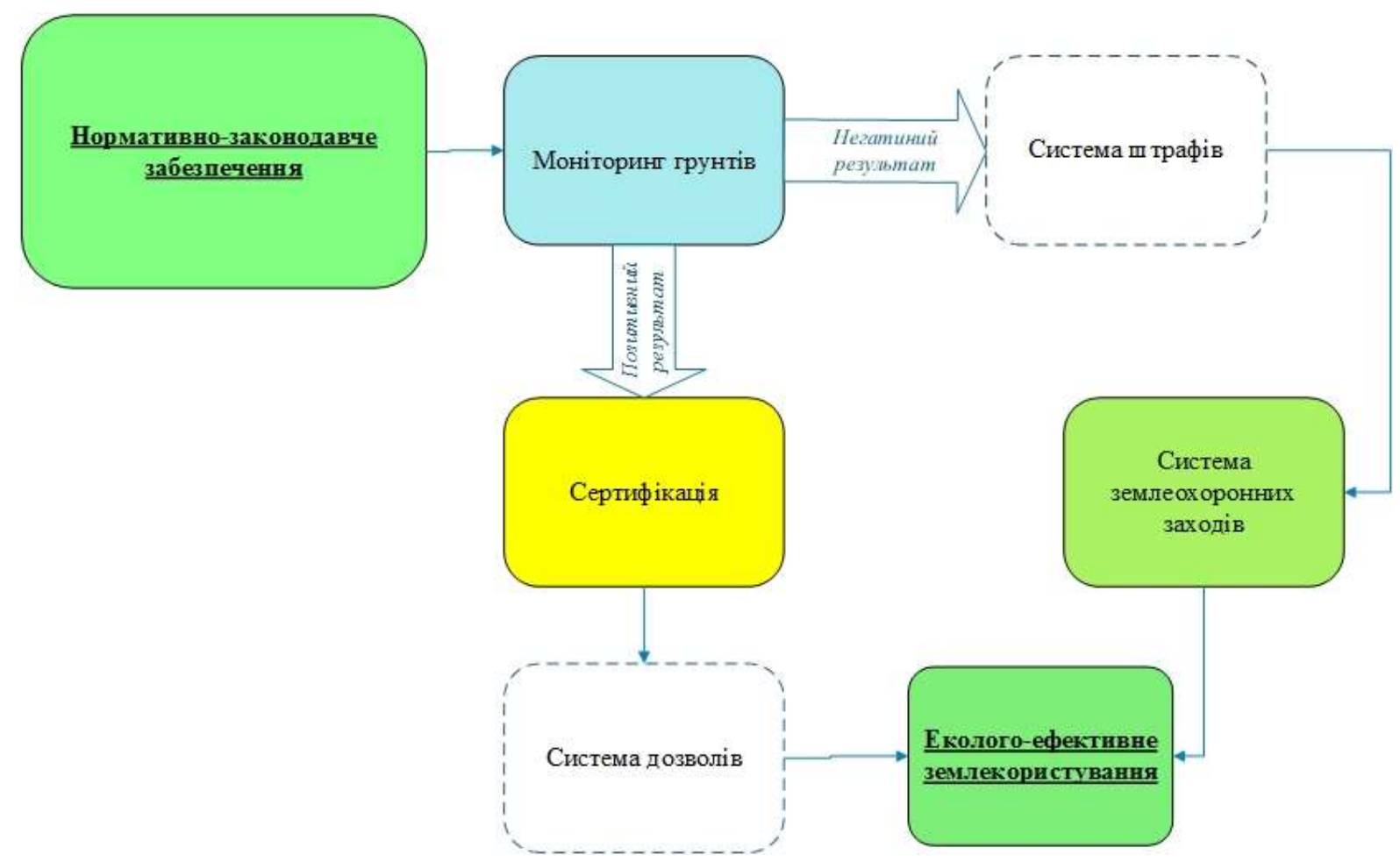

Рис. 4. Схема організаційно-економічного удосконалення реалізаиії землеохоронної діяльності Джерело: авторська розробка

Згідно викладеного підходу, відправним пунктом функціонування цієї системи $є$ результати моніторингової оцінки. Якщо результати таких оцінок $\epsilon$ відповідними до вимог якості грунтового покриву, сертифікаційний орган надає дозволи 3 обмеженим терміном (припустим, на п'ять років) на реалізацію діяльності із землекористування з метою товарного виробництва рослинницької продукції за групами культур. Для збереження відповідної якості грунтового покриву застосовується система землеохоронних заходів звуженого характеру, які повинні запроваджуватись господарюючими суб'єктами. Метою заходів $є$ збереження нормативно встановлених запасів гумусу та збереження прийнятного рівня родючості земель $\mathrm{i}$ агроресурсного потенціалу. До їх числа належать дотримання сівозмін, внесення добривних матеріалів за науково обгрунтованими нормативами.

У випадку, якщо результати моніторингових оцінок виявляються нижчими від встановлених нормативних порогових значень якісних характеристик грунтів, то дозволи видані бути не можуть. Землекористувач отримує перелік рекомендацій щодо запровадження землеохоронної діяльності. Система заходів у цьому випадку орієнтована на відновлення агроекологічної рівноваги. До кола цих заходів можуть належати, наприклад: розширення площ сіножатей, пасовищ та багаторічних насаджень, тобто екологічно стабілізуючих угідь. Крім того, у випадку такої необхідності передбачається розробка системи рекомендацій щодо реалізації заходів iз рекультивації земель. На землекористувача накладається зобов'язання штрафних виплат за погіршення якісних характеристик грунтового покриву на агроугіддях в результаті товарного виробництва рослинницької продукції. Отримані кошти мають надходити на окремий рахунок $\mathrm{i}$ використовуватись за цільовим призначенням для фінансування землеохоронних заходів на землях державної власності, результати яких теж підлягають контролю.

3 іншої сторони потребує удосконалення та посилення комплекс економічних важелів стимулюючого спрямування через пільгові умови кредитування та оподаткування для підтримки товаровиробників.

На основі викладеної інформації очевидним є висновок, що нарощування прибутків та збільшення обсягів товарного виробництва рослинництва супроводжується підвищенням антропогенних навантажень на агроекосистему. Подібний підхід до організації землекористування обмежений рівнем агроресурсного потенціалу, темпи виснаження якого постійно збільшуються, що підтверджується поширенням ерозії та деградації, обсягами втрати 
природної родючості грунтів на агроугіддях та змушує землекористувачів залучати до використання додаткові ділянки за рахунок екологостабілізуючих угідь.

Цим обумовлена необхідність здійснення організаційно-економічних змін, залучення системи економічних, нормативно-законодавчих важелів до процесу товарного виробництва рослинництва для забезпечення стабільно збалансованої рівноваги між економічними інтересами товаровиробників і екологічними запитами суспільства. Таким чином, назріла необхідність впровадження реформ сектору сільськогосподарського виробництва, 3 посиленням відповідальності землекористувачів за якісний стан грунтового покриву.

Система заходів забезпечення збалансованого використання земель походить від системи факторів агроекологічної безпеки, чим визначається їх структуризація, а саме їх групування за видами: територіально-просторові, технологічні, організаційно-економічні, еколого-економічні та соціальні.

До групи територіально-просторових заходів можна віднести:

- оптимізація структури земельних угідь 3 метою забезпечення балансу у співвідношенні площ території регіону під екологостабілізуючими і агроугіддями шляхом розширення діяльностей 3 лісовідновлення, лісорозведення, проведення залуження, відновлення водно-болотних екосистем, лісонасаджень на водорозділах, а також захисних насаджень об'єктів гідросфери;

- вилучення $з$ сільськогосподарського обробітку деградованих, еродованих земель і в першу чергу, ділянок схилів 3 крутизною $7^{0}$;

- удосконалення структури посівів на земельних угіддях сільськогосподарського призначення, яка спрямована на досягнення мінімальних рівнів антропогенного навантаження на агроекостистему;

- оптимізації структури землеволодінь 3 метою мінімізації дрібноконтурності полів та системи польових доріг.

Група технологічних заходів орієнтована на виконання комплексу задач, набір яких різниться за агрокліматичними зонами та має враховувати ряд місцевих особливостей:

- координації схеми внесень добрив;

- координації схеми механічної обробки земель, що передбачає певну послідовність застосування оранки різної глибини за певні проміжки часу із застосуванням меліорантів;

- використання кращих практик у технологіях землекористування 3 врахуванням міжнародного досвіду.

Група організаційно-економічних заходів спрямована на запровадження оновлених умов господарювання, за яких досягнення позитивних рівнів економічної ефективності забезпечується за умови збереження агроресурсного потенціалу, що вимагає удосконалення нормативно-законодавчої регуляторної основи шляхом прийняття ряду документів, спрямованих на:

- відтворення і збереження родючості грунтів;

- завершення формування i запровадження системи інвентаризації та моніторингу родючості агроугідь;

- законодавче закріплення вимог через систему нормативів: якісних характеристик основних типів грунтів, територіально-просторових технологічних параметрів землекористування, системи удобрення тощо;

- системи моніторингу і контролю з одночасним формуванням, розвитком та запровадженням системи економічних стимулів і важелів 3 дотримання означених нормативних вимог.

Еколого-економічна група заходів орієнтована на пом'якшення антропогенних впливів на процеси зміни клімату та адаптації агровиробництва до iï наслідків, відтворення і збереження біорізноманіття, розширення природоохоронних територій тощо.

Соціально-економічна група заходів повинна бути зорієнтована на досягнення імперативів, індикаторів та показників забезпечення збалансованого використання земельних угідь сільськогосподарського призначення, які сигналізують про поліпшення демографічної ситуації через упередження відтоку 3 сільських територій населення, i перш за все працездатного віку, підвищення рівня професійної підготовки кадрів, тощо.

Висновки. На основі аналізу статистичної бази доведено, визначено систему факторів агроекологічної безпеки, окреслено масив показників їх впливу та підкреслено, що їх збалансоване співвідношення забезпечить формування еколого стійких агроландшафтів. Досягнення окресленої мети потребує активізації інституціонального забезпечення у напрямку 
посилення нормативно-законодавчого закріплення параметрів еколого-економічної оптимальності використання земель сільськогосподарського призначення. Оптимальним можна назвати такий спосіб використання земельних ресурсів, за якого відбувається досягнення позитивних показників рентабельності (прийнятного рівня економічної ефективності) товарного агровиробництва і збереження агроресурсного потенціалу, чим забезпечується формування еколого стійких агроландшафтів.

Реалізація зазначених заходів потребує удосконалень нормативно-законодавчого та інституційного характеру щодо завершення розбудови системи інвентаризації і моніторингу та розвитку системи сертифікації земель 3 послідуючою видачою дозволів на реалізацію товарного виробництва певних видів сільськогосподарських культур. 3 іншої сторони потребує удосконалення та посилення комплекс економічних важелів стимулюючого спрямування через кредитування та оподаткування для підтримки товаровиробників. Показано, що запровадження вільного економічного обігу земельних ділянок сільськогосподарського призначення $є$ умовою активізації системи економічних важелів стимулюючого спрямування та сприятиме зебезпеченню прийнятного рівня агроекологічної безпеки.

Врахування окресленого способу збереження агроресурсного потенціалу при розробці державних програм 3 охорони родючості грунтів здатне забезпечити позитивні екологоекономічні результати.

\section{ЛIТЕРАТУРА}

1. Van Mansvelt J. D. Landscape and Agriculture. International Conference on Organic Agriculture, Biodiversity and Business. 2009:16-24.

2. Шевченко І. П. Оптимізація агроландшафтних систем як основа збалансованого розвитку аграрного виробництва [Електронний ресурс] / Землеробство. - Режим доступу: http://www.irbis-nbuv.gov.ua/cgibin/irbis nbuv/cgiirbis 64.exe?I21DBN=LINK\&P21DBN=UJRN\&Z21ID $=\& S 21$ REF $=10 \& S 21 C N R=20 \& S 21$ 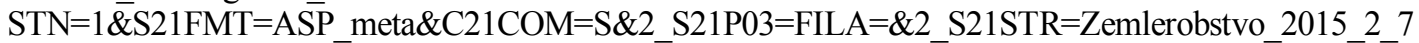

3. Николаев В.А. Концепция агроландшафта. Вестник московского университета. 1987 2(5): $\overline{2} 2-27$.

4. Н.А. Третяк. Підходи до оцінки ефективності управління земельними ресурсами та землекористуванням [Електронний ресурс] - Землеустрій, кадастр і моніторинг земель. - Режим доступу: http://www.irbisnbuv.gov.ua/cgi-

bin/irbis_nbuv/cgiirbis_64.exe?I21DBN=LINK\&P21DBN=UJRN\&Z21ID=\&S21REF=10\&S21CNR=20\&S21 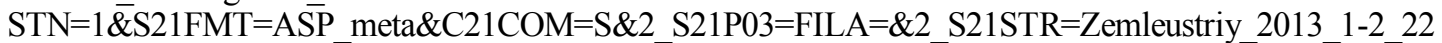

5. Рослинництво України 2017. Статистичний збірник [Електронний ресурс] - Державна служба статистики України. - Режим доступу: https://ukrstat.org/uk/druk/publicat/Arhiv_u/07/Arch_rosl_zb.htm

6. Сільське господарство України 2017. Статистичний збірник [Електронний ресурс] - Державна служба статистики України. Р http://www.ukrstat.gov.ua/druk/publicat/kat_u/2018/zb/09/zb_sg2017_pdf.pdf

7. Статистичний щорічник України за $201 \overline{7}$ рік [Електронний ресурс] - Державна служба статистики України. - Режим доступу: https://ukrstat.org/uk/druk/publicat/kat_u/2018/zb/11/zb_seu2017_u.pdf

8. Внесення мінеральних та органічних добрив у сільськогосподарських підприємствах під урожай сільськогосподарських культур 2017 року [Електронний ресурс] - Державна служба статистики України. - Режим доступу: http://lg.ukrstat.gov.ua/sinf/shoz/vmineral_org_dobruv_2017.htm

9. Інформація про структуру земельного фонду за основними видами угідь $\overline{\mathrm{i}}$ функціональним їх використанням [Електронний ресурс] - Державна служба України з питань геодезії, картографії та кадастру. - Режим доступу: http://land.gov.ua/

10. Пташиний послід: отримання, компостування та норми внесення. Правила выращивания овощей, фруктов, цветов. [Електронний ресурс] - Советы огородникам. - Режим доступу: http://agroazbuka.com/uk/poslid.html

11. Коренюк П., Чмуленко Н. Методика оцінки ефективності використання та відтворення продуктивних угідь сільськогосподарських підприємств. Економіст. 2012. 1(1): 47 - 50.

12. Національна доповідь про стан родючості грунтів України [Електронний ресурс] - Міністерство аграрної політики України. - Режим доступу: http://www.iogu.gov.ua/wp-content/uploads/2013/07/stan_gruntiv.pdf

13. Результати наукових досліджень підготовлено на основі матеріалів X туру (2011-2015 pр.) агрохімічного обстеження земель сільськогосподарського призначення [Електронний ресурс] - ДУ «Інститут охорони грунтів України». - Режим доступу: http://www.iogu.gov.ua/pasportizaciya/ahrohimichne-obstezhennyasilskohospodarskyh-uhid/

14. ДСТУ 4362:2004 Якість грунту. Показники родючості грунтів. [Електронний ресурс] - Міністерство аграрної політики України. - Режим доступу: https://www.twirpx.com/file/1383667/ 